\title{
Valtion koulutuskeskuksen julkaisut
}

Valtion koulutuskeskus on julkaissut lähes koko toimintansa ajan henkilöstökoulutustyötä tukevaa oppimateriaalia. Monissa oppimateriaalijulkaisuissa painottuu erityisesti julkisen hallinnon näkökulma.

Opetussuunnitelmatyön myötä on oppimateriaalien julkaisemiseen tullut enemmän systemaattisuutta. Suurinta osaa julkaisuista käytetään jonkin koulutustilaisuuden tai -tilaisuussarjan ennakko-opiskelumateriaalina tai koulutustilaisuuden aikana varsinaisen opetuksen tukena.

Vuoden 1982 alusta lähtien on VKK:n julkaissut ryhmitetty kolmeen sarjaan: julkaisusarja A sisältää kirjamuotoiset julkaisut, julkaisusarja B varsinaiset oppimateriaaliraportit. Kolmas sarja on nimeltään Valtion koulutuskeskuksen tutkimuksia ja selvityksiä.

Viimeaikaisen opetusta koskevan keskustelun pohjalta voi nostaa esille muutamia Bsarjan julkaisuista.

Eräitä opetuksen suunnittelun erityiskysymyksiä henkilöstökoulutuksessa-nimisessä raportissa (B n:o 8, 1979) käsittelee Yrjö Engeström orientoinnin merkitystä opetuksessa, Veikko Teikari työtapahtuman analyysiä sekä ammatinanalyysiä ja Ritva Jakku-Sihvonen opetusmenetelmän käsitettä sekä menetelmävalintaa.

Johdatusta didaktiikkaari -raporttia (Engeström, 1981) on käytetty VKK:n kouluttajakoulutuksen perusoppimateriaalina. Siinä luonnehditaan opetuksen pääkäsitteitä erityisesti kognitiivisen opetus-oppimiskäsityksen pohjalta.
Henkilöstökoulutuksen erityisluonteen kannalta on Jaakko Virkkusen ja Reijo Miettisen laatima raportti Opetus ja työstä oppiminen henkilöstön kehittämisessä (B n:o 14, 1981) tärkeä. Raportissa pohditaan henkilöstön pätevyyden kehittämisen ongelmaa, koulutusta hallintotieteen sekä ammattien sosiologian näkökulmasta sekä osoitetaan didaktiikka-tieteen asettamat ehdot hyvän työpaikkakoulutuksen toteuttamiselle.

Vuoden 1982 aikana ilmestyy B-sarjassa kaksi mielenkiintoista raporttia. Raportissa Kognitiivisen oppimisnäkemyksen tausta käsittelee Reijo Miettinen hyvinkin seikkaperäisesti nykyaikaiseen kognitiiviseen oppimiskäsitykseen vaikuttaneiden suuntauksien kehitystä. Tätä raporttia on käytetty monistemuotoisena jo VKK:n kouluttajakoulutuksessa.

Kvalifikaatio ja työn vaatimukset koulutuksen suunnittelun lähtökohtana-raportissa kuvaavat Juha Vartola, Kari Toikka ja Anneli Vihmalo kvalifikaatio-käsitettä sekä kvalifikaatioiden arvioinnin metodologian lähtökohtia hallintotieteen, sosiologian sekä psykologian näkökulmista. Myöskin tätä raporttia on käytetty monistemuotoisena VKK:n kouluttajakoulutuksessa.

A- ja B-sarjaan kuuluvia osuuksia voi ostaa Valtion painatuskeskuksesta, PL 516, Annank. 44, 00101 HKI 10. Puhelintilaukset 90539011.

Seuraavassa on luettelo VKK:n julkaisuista:
Selkeä virkakiıli A 1, 1980 Esko Koivusalo \& Liisa Huovinen-Nyberg

Ryhmätyön käyttö koulutuksessa A 2, 1981

Koulutustarpeen arviointi henkilöstökoulutuksessa

B n:o 1, 1977

Koulutuksen kustannukset ja vaikutukset

B n:o 2, 1978
Työelämän aikuisopetuksen kehittämisen teoreettisia lähtökohtia

Jaakko Virkkunen

B n:o 4, 1978

Valtion henkilöstöhallinnon käsitteistö

B n:o 5, 1979

Valtion henkilöstökouluttajien ammattikuvatutkimus

Eva Launos \& Seppo Peisa

B n:o 6, 1979
Opetusprosessin optimointi Pentti Hakkaraisen laatima referaatti J.K. Babanskin teoksesta ',Opetusprosessin optimointi",

B n:o 7, 1979

Eräitä opetuksen suunnittelun erityiskysymyksiä henkilöstökoulutuksessa

Yrjö Engeström, Veikko Teikari ja Ritva Jakku-Sihvonen

B n:o 8, 1979 
Toimistotyö ja -ammatti julkisessa hallinnossa

Reijo Miettinen

B n:o 9, 1980

Ajattelu, oppiminen ja opetus Mikko Korkiakangas \& Pentti Hakkarainen

B n:o 10, 1980

Käytännön pienvideotekniikkaa

Erkki Kivi

B n:o 11, 1980

Valtion henkilöstökouluttajien jatkokoulutusohjelman opetussuunnitelma

B n:o 12, 1980

Johdatusta didaktiikkaan

Yrjö Engeström

B n:o 13, 1981

Opetus ja työstä oppiminen henkilöstön kehittämisessä Jaakko Virkkunen \& Reijo Miettinen

B n:o 14, 1981

Ryhmätyöskentelyn teoreettisia perusteita

Klaus Helkama

B n:o 15, 1981

Training Programme Curriculum for In-Service Trainers in Finnish State Administration

B n:o 16, 1981
Mielekäs oppiminen ja opetus

Yrjö Engeström

B n:o 17, 1981

Kognitiivisen oppimiskäsityksen tausta

Reijo Miettinen

(ilmestyy 1982)

Kvalifikaatio ja työn vaatimukset koulutuksen suunnittelun lähtökohtana

Kari Toikka \& Juha Vartola \& Anneli Vihmalo

(ilmestyy 1982)

Opetussuunnitelman käsite ja kehitys

Yrjö Engeström

(ilmestyy 1982)

\section{JULKAISUSARJA VKK:N TUTKIMUKSIA JA SELVI- TYKSI ̈̈}

Tavoitteisuus ja opettamisprosessi

- observointiin ja haastatteluun perustuva tutkimus VKK:ssa tuotetusta opetuksesta

Ritva Jakku-Sihvonen

n:o 1,1981

Objectives and Teaching in InService Training

- a Study on the Training at the
State Training Centre Based on Observations and Interviews

Ritva Jakku-Sihvonen n:o 2, 1981

VKK:N TUOTTAMAT VAPK:N MYYNNISSÄ OLEVAT JULKAISUT

Valtioneuvoston esittelijän asema ja tehtävät

toim. Jorma Hirvonen, 1974

Perustietoa valtionhallinnosta toim. Jorma Hirvonen, 1975

Perustietoa johtamisesta toim. Jorma Hirvonen, 1976

Perustietoa valtionhallinnosta koulutuksen suunnittelijalle toim. Jorma Hirvonen, 1977

Puhelinkäyttäytyminen

Kerttu Poutiainen, 1978

Toimistotyön kehittäminen

Timo Alhola \& Teuvo Tuominen \& Pasi Haikola 1980

Valtion palvelussuhteen ehdoista 1980 